Eur. J. Clin. Chem. Clin. Biochem.

Vol. 29, 1991, pp. 665-674

(C) 1991 Walter de Gruyter \& Co.

Berlin - New York

\title{
Preparation of Nucleoside-LDL-Conjugates for the Study of Cell-Selective Internalization: Stability Characteristics and Receptor Affinity
}

\author{
By H.-W. Schultis ${ }^{1,4}, H$. v. Baeyer ${ }^{2}$, Heidemarie Neitzel $^{3}$ and E. Riedel ${ }^{1}$ \\ 1 Institut für Biochemie, Freie Universität Berlin \\ ${ }^{2}$ Medizinische Klinik und Poliklinik, Klinikum Rudolf Virchow, Freie Universität Berlin \\ 3 Institut für Humangenetik, Freie Universität Berlin \\ ${ }^{4}$ Institut WILAB GmbH, Baiersdorf, Germany
}

(Received January 18/June 28, 1991)

Summary: Antiviral therapy of human immundeficiency virus (HIV) infection is currently based on inhibition of reverse transcriptase by dideoxynucleosides, such as azidothymidine. Because of widespread toxicity it is reasonable to selectively target these drugs to infected cells. This may be accomplished utilizing drug-LDL conjugates, which are internalized via cell specific receptor pathways. With respect to HIV infection, scavenger receptors of the macrophage system seems to offer a hopefull perspective. This pathway requires chemical modification of surface polarity of the LDL. Cell experiments were conducted in HepG2 hepatocytes, which express apolipoprotein $\mathrm{B}$ receptors, and in $\mathrm{P}_{388}$ macrophages, which express scavenger receptors. LDL particles to be conjugated were isolated from blood donor plasma and from LDL-apheresis waste material. Noncovalent LDL conjugation with amphiphilic nucleoside derivatives produced only an unspecific nucleoside transfer to cell membranes, due to instability of the LDL conjugates. An experimental method (coincubation test) was developed to identify those conjugates that are stable in the presence of other lipophilic compartments. Covalent coupling of nucleosides to the apolipoprotein B moiety of LDL particles resulted in stable conjugates. As a consequence, the surface charge became negative, and the LDL displayed scavenger receptor affinity rather than apolipoprotein $B$ receptor affinity. Selective targeting of nucleosides to macrophages can be accomplished by covalent coupling to LDL.

\section{Introduction}

The concept of drug targeting dates back to the ingenious ideas of Paul Ehrlich (1). Since the recognition of receptor-mediated LDL-uptake in tumour cells $(2-6)$, drug targeting of cytotoxic agents via $\left.\mathrm{LDL}^{1}\right)$ has been envisiged as a means of improving the chemotherapy of neoplastic diseases (7). However, despite many efforts, no practicable regime of cellselective delivery of a LDL-drug-conjugate has so far been developed. This is mainly due to the failure to obtain stable LDL-drug-conjugates $(8,9)$ : Moreover,

') Abbreviations: LDL, low density lipoprotein; HIV, human immunodeficiency virus. it has been shown that enrichment via the apolipoprotein $B$ receptor pathway is insignificant $(8-10)$.

Targeted drug delivery is also an attractive proposition for the treatment of viral diseases. These diseases may be treated effectively by antimetabolites, such as azidothymidine $(15,16)$, which cause termination of DNA chain elongation in the infected cell, and are therefore able to curtail the life cycle of HIV ${ }^{1}$ ). However, systemic toxicity to the haemapoetic and neural system has hindered long-term high dose regimes with these agents.

Recently, it was found that the mononuclear-phagocytic cell system serves as a virus reservoir in HIV 
infection $(11-15)$. This cell family possesses scavenger receptors, in contrast to the ubiquitous LDL apolipoprotein B receptor that are found, e.g. on blood monocytes, $\mathrm{B}$ and $\mathrm{T}$ lymphocytes and hepatocytes $(17,18)$. Thus, utilization of the scavenger receptor pathway may avoid drug delivery to sensitive albeit non-infected cells. Drug delivery via this receptor has not been previously suggested. Linkage of azidothymidine or antisense oligonucleotides to LDL, in a way that favoured selective scavenger receptor uptake by macrophages, would offer a new route for antiviral chemotherapy.

The aim of our work was to obtain stable nucleoside/ LDL conjugates, which will be taken up selectively by the scavenger receptor of macrophages. It was intended to prepare stable nucleoside-LDL conjugates and to modify these conjugates in order to utilize scavenger receptor transport.

\section{Materials and Methods}

\section{Compounds}

Trityl-azidothymidine, $\quad 5^{\prime}$-O-trityl-3'-azido-2'. $3^{\prime}$-deoxythymidine, 5'-O-stearoyl-3'-azido-2'.3'-deoxythymidine, 5'-O-erucoyl-3'-azido-2'. ' $^{\prime}$-deoxycytidine, $\left[{ }^{3} \mathrm{H}\right] 4^{\prime}$ - $\mathrm{N}$-stearoyl-2'-deoxycytidine were prepared as described in 1.c. (19).

\section{Electrophoresis}

SDS-PAGE was performed according to the method of Cardin et al. (22) modified as previously described (23). Agarose lipoprotein electrophoresis was conducted with the Paragon Lipo Kit (Fa. Beckman).

\section{Chemical analysis}

Total cholesterol was determined using the cholesteroloxidase/ 4-aminophenazone method, Monotest (Boehringer Mannheim, Germany); protein was determined according to Lowry et al. (24).

\section{Isolation of LDL particles}

LDL was isolated from citrated plasma of blood donors (courtesy Dr. Eckstein), and from membrane differential filtration apheresis (20). LDL (fraction $\mathrm{d}=1.019-1.063 \mathrm{~kg} / \mathrm{l}$ ) and lipoprotein-deficient serum ( $>1.21 \mathrm{~kg} / \mathrm{l})$ were prepared by sequential ultracentrifugation (21). LDL fractions were dialysed $36 \mathrm{~h}$ against standard buffer $(0.15 \mathrm{~mol} / 1 \mathrm{NaCl}, 0.5 \mathrm{mmol} / 1$ EDTA, pH $7.4,4^{\circ} \mathrm{C}$ ). Defibrination of lipoprotein-deficient serum was performed by incubation with thrombin $\left(20 \cdot 10^{3}\right.$ $\mathrm{NIH} \mathrm{U/l)}$ at $24^{\circ} \mathrm{C}$ for $10 \mathrm{~min}$, and centrifugation at $30000 \mathrm{~g}$ for $90 \mathrm{~min}$. The purified fractions were sterile filtered over 0.22 $\mu \mathrm{m}$ Millex filter (Millipore Co.) and stored at $4{ }^{\circ} \mathrm{C}$.

\section{Iodination of LDL}

LDL was ${ }^{125} \mathrm{I}$-labelled by the $\mathrm{ICl}$ method of Karlin et al. (25), purified over Sephadex $G 75$ columns $(20 \times 1 \mathrm{~cm})$ and dialysed against standard buffer. The trichloroacetic acid precipitates contained $97-99 \%$ of the radioactivity. The specific activity was $200-600$ counts/min per ng protein.

\section{Acetylation of LDL}

LDL apheresis-derived material was acetylated by the method of Basu et al. (26) and dialysed for $36 \mathrm{~h}$ at $4{ }^{\circ} \mathrm{C}$ against standard buffer. Occasionally turbidity was removed by centrifugation $(12000 \mathrm{~g}, 20 \mathrm{~min})$. Sterile filtration was conducted as above.

\section{Cell transport tests}

is

Human hepatocytes (HepG2, American tissue culture collection) were used. These cells were routinely screened for mycoplasma infection. Culturing was performed with Eagles minimum essential medium containing fetal calf serum, volume fraction 0.1 , at $37^{\circ} \mathrm{C}$ and $5 \% \mathrm{CO}_{2}$. For transport experiments the cells were trypsinised ( $0.5 \mathrm{~g} / 1$ trypsin, $0.5 \mathrm{~g} / 1$ EDTA) and transferred into dishes $(60 \times 15 \mathrm{~mm})$. On day four, the culture medium was replaced by lipoprotein-deficient serum, volume fraction 0.1 , containing medium for 12 to $18 \mathrm{~h}$. The cell protein concentration at this time was $1-2 \mathrm{mg} / \mathrm{dish}$. Binding, incorporation and degradation was determined according to Goldstein \& Brown (27).

Murine macrophages $\left(\mathrm{P}_{388}\right.$, American tissue culture collection) were cultured in RPMI medium with addition of non-essential amino acids and fetal calf serum, volume fraction 0.1 . For transport tests, the cells were suspended and transferred into dishes $(35 \times 15 \mathrm{~mm})$. When surviving cells became adherent $(1 \mathrm{~h})$, medium was exchanged. LDL uptake was determined by quantification of intracellular cholesterol ester using an HPTLC method (28).

Conjugation of amphiphilic nucleoside derivatives to $\mathrm{LDL}$

The conjugation was a modification of a method of Havekes et al. (29). The incubation mixture contained $2.5 \mathrm{~g}$ LDL (protein) per litre final volume (standard buffer) and lipoproteindeficient serum, volume fraction 0.25 . The nucleoside derivatives were added as methanolic solutions (acyl-derivatives: $2 \mathrm{~g} / \mathrm{l}$; trityl-derivatives: $10 \mathrm{~g} / \mathrm{l}$ ) and incubated for $24 \mathrm{~h}$ at $37^{\circ} \mathrm{C}$. Reisolation of $\mathrm{LDL}$ was performed by ultracentrifugation after addition of $\mathrm{KBr}(125 \mathrm{~g} / \mathrm{l})$ at $250000 \mathrm{~g}$ for $22 \mathrm{~h}$. LDL conjugates float, whereas free amphiphilic nuicleoside derịatives are pelleted.

\section{Quantification of nucleoside binding to LDL}

The binding of ${ }^{3} \mathrm{H}$-labelled nucleosides to LDL was determined by calculation of specific activity per mg of LDL-protein. An aliquot $(0.5 \mathrm{ml})$ of $\mathrm{LDL}$ nucleoside conjugate or acetyl-LDL nucleoside conjugate (approx. $500 \mu \mathrm{g}$ protein) was lyophilised and extracted with $1 \mathrm{ml}$ methanol for $24 \mathrm{~h}$ at room temperature. After centrifugation, the nucleoside extract was subjected to HPLC on RP 18. The eluent was acetate buffer ( $\mathrm{pH} 7.2,50$ $\mathrm{mmol} / \mathrm{l}) /$ methanol in the proportion $15 / 85$, by volume, for trityl-azidothymidine and $5 / 95$, by volume for acyl-azidothymidine. Detection was at UV $265 \mathrm{~nm}$.

\section{Stability tests}

\section{Heparin precipitation}

An aliquot $(0.5 \mathrm{ml})$ of LDL-nucleoside conjugate was mixed with $0.5 \mathrm{ml}$ acetate buffer ( $\mathrm{pH} 4.6 ; 100 \mathrm{mmol} / \mathrm{l} \mathrm{Na}$-acetate, 200 $\mathrm{mmol} / \mathrm{l} \mathrm{NaCl}$ ), incubated with $500 \mathrm{IU}$ heparin $(25 \mu \mathrm{l})$ for 15 $\mathrm{min}$ at room temperature, then centrifuged (15 min, $12000 \mathrm{~g}$ ). The supernatant was discarded; the pellet was extracted with methanol $(1.0 \mathrm{ml})$. Further processing was performed as described above by HPLC or ${ }^{3} \mathrm{H}$-labelling. The fraction of heparin-precipitated LDL-nucleoside was calculated from the initial total amount of nucleoside. The same procedure was per- 
formed for acetylated LDL using citric acid (pH 2.2; 100 $\mathrm{mmol} / \mathrm{l}$ ) for incubation with heparin.

\section{Dialysis}

The LDL conjugates were dialysed at $37^{\circ} \mathrm{C}$ against standard buffer as indicated. Bound nucleoside derivatives were quantified by ${ }^{3} \mathrm{H}$-labelling or HPLC.

\section{Equilibrium dialysis}

LDL nucleoside conjugate solution $(200 \mu \mathrm{l})$ dialysed against the same volume of buffer as indicated for $24 \mathrm{~h}$ at $37^{\circ} \mathrm{C}$. The nucleoside redistribution on both sides of the dialysis membrane was determined by quantification of the bound fraction as above.

\section{Sephadex gel chromatography}

$\left[{ }^{3} \mathrm{H}\right] 4^{\prime}$-N-stearoyl-2'-deoxycytidine/LDL conjugate $(2.5 \mathrm{mg}$ protein) was eluted over Sephadex G $75(30 \times 1.8 \mathrm{~cm})$ with $\mathrm{KH}_{2} \mathrm{PO}_{4}$ (pH 7.4, $\left.50 \mathrm{mmol} / 1\right)$. Fractions of $1 \mathrm{ml}$ were measured for cholesterol and ${ }^{3} \mathrm{H}$ activity (nucleoside).

\section{Coincubation test}

A mixture of nucleoside-LDL (2 $\mathrm{mg}$ cholesterol) and acetylLDL ( $2 \mathrm{mg}$ cholesterol) was incubated in $3 \mathrm{ml}$ acetate buffer (100 mmol/l Na-acetate, $200 \mathrm{mmol} / \mathrm{l} \mathrm{NaCl}, \mathrm{pH} \mathrm{4.6)}$ at room temperature for various periods of time (fig. 5). NucleosideLDL-conjugates were precipitated by addition of $25 \mu$ l heparin (500 IU), and removed by centrifugation (10 min, $12000 \mathrm{~g})$. Acetylated LDL and acetylated LDL-nucleoside-conjugates remain in the supernatant (30).

\section{Covalent ligand coupling}

Covalent coupling of thymidine to LDL (from membrane differential filtration apheresis) was achieved by covalent coupling of 4-nitrophenyl- $\left[{ }^{3} \mathrm{H}\right]$ thymidine- 5 '-carbonate (synthesized as described in 1. c. (19)) with the apolipoprotein B moiety of LDL by stepwise addition of 4-nitrophenyl- $\left[{ }^{3} \mathrm{H}\right]$ thymidine- $5^{\prime}$-carbonate $(10 \mathrm{mg}$ in $125 \mu \mathrm{l}$ methanol) to borate-buffered $(250 \mathrm{mmol} / \mathrm{l}$, $\mathrm{pH}$ 10.0) LDL-solution, with stirring at $4^{\circ} \mathrm{C}$. The reaction solution was centrifuged $(15 \mathrm{~min}, 12000 \mathrm{~g}$ ) to remove insoluble components and denaturated LDL. The supernatant was purified by sephadex gel chromatography (Sephadex G 75, $20 \times 1$ $\mathrm{cm})$. The LDL containing fractions were pooled and analysed for protein and ${ }^{3} \mathrm{H}$ activity.

\section{Results}

At first, we studied the stability of LDL conjugates, which were prepared by equilibrium techniques, using conventional stability tests. LDL and acetylated LDL were conjugated with lipophilised nucleosides (trityl-, O-stearoyl-azidothymidine, $\left[{ }^{3} \mathrm{H}\right] 4^{\prime}$ - $\mathrm{N}$-stearoyl-2'-deoxycytidine) (tab. 1, tab. 2): all tested LDL conjugates showed $>95 \%$ stability in heparin precipitation. However, trityl-azidothymidine/LDL conjugates revealed an unacceptable instability in standard dialysis: dissociation occurred at $37^{\circ} \mathrm{C}$ with a half-life of $8 \mathrm{~h}$ (fig. 1). Trityl-azidothymidine was therefore excluded from further experiments. The acyl-nucleoside derivatives exhibited sufficient stability during standard

Tab. 1. Stability test of LDL conjugates by equilibrium dialysis: $\left.200 \mu 1{ }^{3} \mathrm{H}\right] 4^{\prime}$ - $\mathrm{N}$-stearoyl-2'-deoxycytidine/LDL-conjugate against $200 \mu \mathrm{l}$ dialysis buffer for $20 \mathrm{~h}$ at $37^{\circ} \mathrm{C}$. Drug conjugation was calculated from ${ }^{3} \mathrm{H}$ activity. The activity remaining after dialysis was taken to represent the conjugated fraction, and expressed as a percentage.

\begin{tabular}{|c|c|c|}
\hline $\begin{array}{l}\text { Dialysate } \\
200 \mu \mathrm{l}\end{array}$ & $\begin{array}{l}\text { Dialysis buffer } \\
200 \mu \mathrm{l}\end{array}$ & $\begin{array}{l}\text { Conjugated fraction } \\
\text { (\% of total activity) }\end{array}$ \\
\hline$\left[{ }^{3} \mathrm{H}\right] 4^{\prime}$-N-stearoyl-2'-deoxycytidine/LDL & $\begin{array}{l}\text { Isotonic } \mathrm{NaCl} \\
\text { Eagle-medium } \\
\text { Eagle + foetal calf } \\
\text { Bovine serum albumin, } 40 \mathrm{~g} / 1 \text { serum, } 100 \mathrm{ml} / 1 \\
\mathrm{LDL}, 10 \mathrm{~g} / \mathrm{l}\end{array}$ & $\begin{array}{l}98.4 \\
97.6 \\
97.8 \\
97.2 \\
97.3\end{array}$ \\
\hline$\left[{ }^{3} \mathrm{H}\right] 4^{\prime}-\mathrm{N}$-stearoyl-2'-deoxycytidine/acetyl-LDL & $\begin{array}{l}\text { Isotonic } \mathrm{NaCl} \\
\text { Eagle-medium } \\
\text { Eagle }+ \text { foetal calf } \\
\text { Bovine serum albumin, } 40 \mathrm{~g} / 1 \text { serum, } 100 \mathrm{ml} / \mathrm{l} \\
\mathrm{LDL}, 10 \mathrm{~g} / \mathrm{l}\end{array}$ & $\begin{array}{l}98.6 \\
98.7 \\
98.5 \\
98.5 \\
98.4\end{array}$ \\
\hline
\end{tabular}

Tab. 2. Summary of stability tests.

\begin{tabular}{|c|c|c|c|}
\hline \multirow[t]{2}{*}{ Method } & \multicolumn{3}{|l|}{ LDL-conjugate } \\
\hline & $\begin{array}{l}\text { LDL/ } \\
\text { Trityl-azidothymidine }\end{array}$ & $\begin{array}{l}\mathrm{LDL} / \\
5^{\prime}-\mathrm{O} \text {-stearoyl-3'-azido- } \\
2^{\prime} \cdot 3^{\prime} \text {-dideoxythymidine }\end{array}$ & $\begin{array}{l}\text { LDL/ } \\
{\left[{ }^{3} \mathrm{H}\right] 4^{\prime}-\mathrm{N} \text {-stearoyl-2'- }} \\
\text { deoxycytidine }\end{array}$ \\
\hline $\begin{array}{l}\text { Heparin precipitation } \\
\text { Dialysis } \\
\text { Equilibrium dialysis } \\
\text { Ultracentrifugation } \\
\text { Gel-chromatography }\end{array}$ & $\begin{array}{l}>95 \% \\
t_{1 / 2}=8 h\end{array}$ & $\begin{array}{l}>95 \% \\
>85 \% \\
>95 \%\end{array}$ & $\begin{array}{r}>95 \% \\
>94 \% \\
97-98 \% \\
>95 \% \\
>70 \%\end{array}$ \\
\hline
\end{tabular}




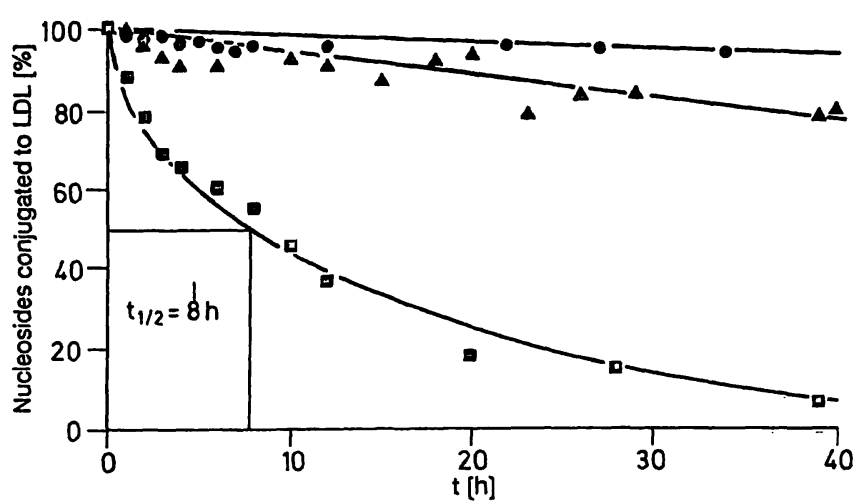

Fig. 1. Stability of nucleoside/LDL conjugates in standard dialysis. Decrease of conjugated nucleosides as a function of time. Dialysis: $34 \mathrm{~h}$ at $37^{\circ} \mathrm{C}$ against 1000 volumes of standard buffer. In the case of $\left[{ }^{3} \mathrm{H}\right] 4^{\prime}-\mathrm{N}$-stearoyl-2'-deoxycytidine/LDL, $81 \%$ of ${ }^{3} \mathrm{H}$ activity before dialysis, and $97 \%$ of ${ }^{3} \mathrm{H}$ activity after dialysis was precipitated with heparin. The unbound ligand was removed during dialysis.

- $\left[{ }^{3} \mathrm{H}\right] 4^{\prime}-\mathrm{N}$-stearoyl-2'-deoxycytidine-LDL

$\Delta 5^{\prime}$-O-stearoyl-3'-azido-2'.3'-deoxythymidine-LDL

a 5'-O-trityl-3'-azido-2'.3'-deoxythymidine-LDL

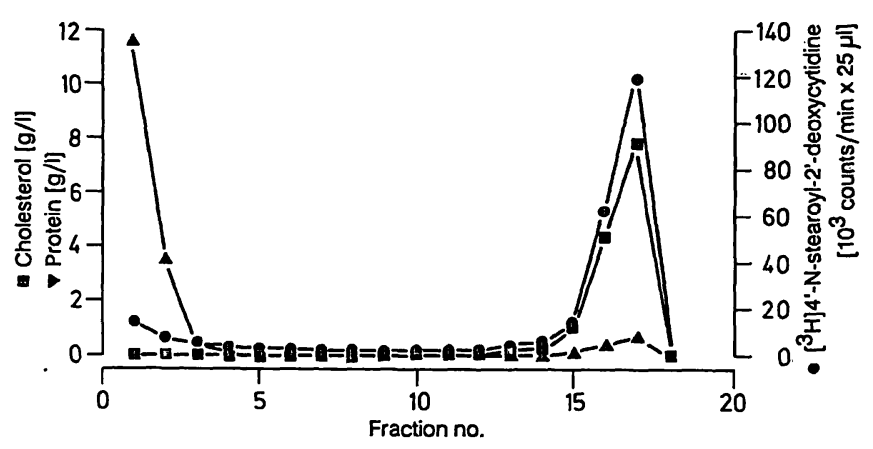

Fig. 2. Reisolation of LDL conjugates from lipoprotein-deficient serum-containing incubation medium (ultracentrifugation with $\mathrm{KBr}$ gradient). 18 fractions ( $625 \mu \mathrm{l}$ each) from bottom (fraction 1) to top (fraction 18) were separated and analysed for total cholesterol, protein (experiment 1 ) and ${ }^{3} \mathrm{H}$ activity (experiment 3 ). $95 \%$ of ${ }^{3} \mathrm{H}$ activity was found with the cholesterol-containing LDL fraction; $5 \%$ was pelleted with proteins of lipoprotein deficient serum. A control run without LDL under identical conditions showed $100 \%$ of ${ }^{3} \mathrm{H}$ activity in the protein pellet.

dialysis $\left(85-94 \%\right.$ binding after $34 \mathrm{~h}$ at $\left.37^{\circ} \mathrm{C}\right)$. Equilibrium dialysis against several media (tab. 1) revealed high stability ( $>97 \%$ binding after $20 \mathrm{~h}$ at $37^{\circ} \mathrm{C}$ ).

Reisolation of LDL ( $\mathrm{d}=1.019-1.063 \mathrm{~kg} / \mathrm{l})$ after substrate conjugation in the presence of lipoproteindeficient serum, volume fraction 0.25 , by ultracentrifugation results in $95 \%$ binding of the initial amount of nucleoside derivative to LDL (fig. 2). Gel chromatography of the LDL-nucleoside conjugate demonstrated $>70 \%$ binding to the eluted LDL. In summary, stability tests were satisfactory with acyl-nu-
cleoside/LDL conjugates prepared by equilibrium methods (tab. 2).

Biological integrity of the LDL conjugates was demonstrated by electrophoretic mobility with SDSPAGE and agarose electrophoresis and by cell transport studies with human hepatocytes (Hep G2) and murine macrophages $\left(\mathrm{P}_{388}\right)$. The experiments showed that conjugation of LDL with amphiphilic nucleoside derivatives via solution equilibrium neither changed electrophoretic mobility, nor modified receptor affinity.

Receptor-mediated ligand internalization of LDLconjugates was determined by ${ }^{3} \mathrm{H}$-labelling of the ligand, or ${ }^{125}$ I-labelling of the LDL particle. Strikingly different transport behaviour was shown by the ${ }^{3} \mathrm{H}-$ labelled and ${ }^{125} \mathrm{I}=$ labelled conjugates (fig. 3). $\left[{ }^{3} \mathrm{H}\right] 4^{\prime}-\mathrm{N}$ stearoyl-2'-deoxycytidine/LDL is ten times more enriched than $4^{\prime}-\mathrm{N}$-stearoyl-2'-deoxycytidine/ $\left[{ }^{125} \mathrm{I}\right] \mathrm{LDL}$, when calculated on the basis of a stable LDL conjugate. In contrast, the nucleoside/acetyl- $\left[{ }^{125} \mathrm{I}\right] \mathrm{LDL}$ conjugate shows almost no internalization. Surprisingly, $\left[{ }^{3} \mathrm{H}\right] 4^{\prime}$-N-stearoyl-2'-deoxycytidine/acetyl-LDL conjugates seem to be transported approximately to the same extent as $\left[{ }^{3} \mathrm{H}\right]-4^{\prime}-\mathrm{N}$-stearoyl-2'=deoxycytidine/ LDL. The difference between the acetylated nucleoside conjugate and the unacetylated species is $10 \%$ in these experiments. Thus, an unspecific nucleoside internalization of $90 \%$ of possible maximal transport $\left(\left[{ }^{3} \mathrm{H}\right] 4^{\prime}\right.$-N-stearoyl-2'-deoxycytidine/LDL) must have been occurred.

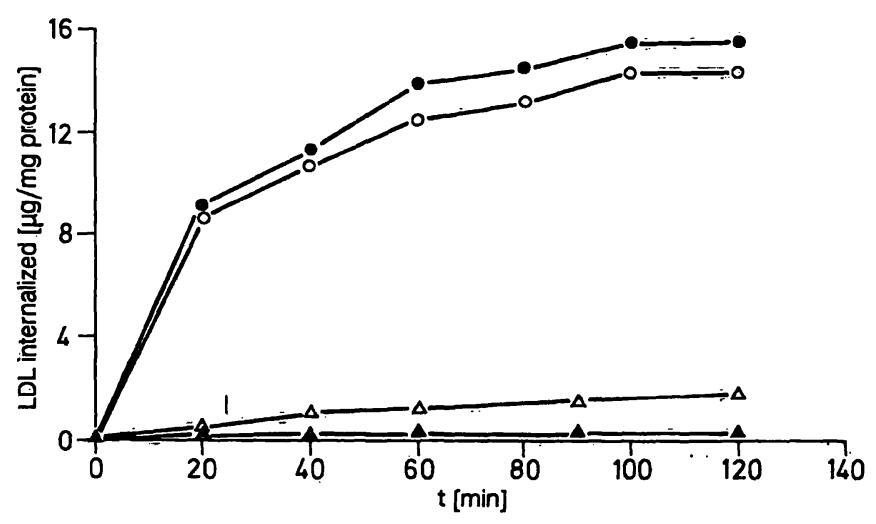

Fig. 3. Internalization tests ( $\mu \mathrm{g} / \mathrm{mg}$ cell protein) on Hep $\mathrm{G} 2$ hepatocytes with $4^{\prime}-\mathrm{N}$-stearoyl-2'=deoxycytidine/LDL or $4^{\prime}$-N-stearoyl-2'-deoxycytidine/acetyl-LDL conjugates. Internalization $(\mu \mathrm{g} / \mathrm{mg}$ cell protein) was determined by $\left[{ }^{125} \mathrm{I}\right] \mathrm{LDL}$ labelling and by ${ }^{3} \mathrm{H}$-ligand labelling of the conjugates. The discrepancy. between both labels is obvious indicating the non-receptor-mediated uptake of the ${ }^{3} \mathrm{H}$-labelled ligand.

- $\left[{ }^{3} \mathrm{H}\right] 4^{\prime}-\mathrm{N}$-stearoyl-2'-deoxycytidine-LDL

O $\left[{ }^{3} \mathrm{H}\right] 4^{\prime}$-N-stearoyl-2'-deoxycytidine-acetyl-LDI

$\triangle 4^{\prime}-\mathrm{N}$-stearoyl-2'-deoxycytidine= $\left[{ }^{125} I\right] \mathrm{LDL}$

$\Delta 4^{\prime}$-N-stearoyl-2' $=$ deoxycytidine-acetyl $\left[{ }^{125} \mathrm{I}\right] \mathrm{LDL}$ 


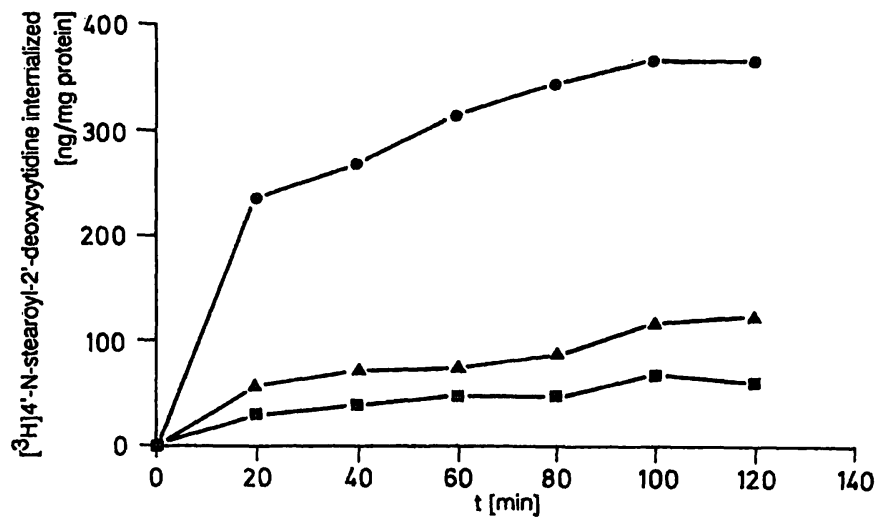

Fig. 4. Internalization tests on Hep $\mathrm{G} 2$ hepatocytes with $\left[{ }^{3} \mathrm{H}\right] 4^{\prime}$ $\mathrm{N}$-stearoyl-2'-deoxycytidine/LDL conjugates in the presence of an competitive binding compartment. A 20 fold excess of native LDL as well as bovine serum albumin, $40 \mathrm{~g} / \mathrm{l}$, reduces the internalization $(\mathrm{ng} / \mathrm{mg}$ cell protein) substantially.

- $\left[{ }^{3} \mathrm{H}\right] 4^{\prime}-\mathrm{N}$-stearoyl-2'-deoxycytidine-LDL

ㅁ $\left[{ }^{3} \mathrm{H}\right] 4^{\prime}$-N-stearoyl-2'-deoxycytidine + LDL

$\Delta\left[{ }^{3} \mathrm{H}\right] 4^{\prime}$-N-stearoyl-2'-deoxycytidine + bovine serum albumin, $40 \mathrm{~g} / 1$

In order to analyse these unexpected findings, competition experiments were conducted (fig. 4). Internalization of $\left[{ }^{3} \mathrm{H}\right] 4^{\prime}-\mathrm{N}$-stearoyl-2'-deoxycytidine in hepatocytes reveals saturation behaviour. When $\mathrm{LDL}$ (acting as a competitive receptor binding agent) and bovine serum albumin (acting as an unspecific lipophilic binding agent) were added to the incubation media, substantial reduction of $\left[{ }^{3} \mathrm{H}\right] 4^{\prime}-\mathrm{N}$-stearoyl-2'deoxycytidine internalization was observed, i. e. $85 \%$ reduction after adding unconjugated LDL and 70\% reduction after adding albumin.
Ultracentrifugation ( $\mathrm{KBr}$ gradient) of the incubation medium used in the competition experiments with LDL excess showed $99 \%$ binding of the $\left[{ }^{3} \mathrm{H}\right] 4^{\prime}-\mathrm{N}$ stearoyl-2'-deoxycytidine activity in the LDL fraction; however, the bovine serum albumin-containing incubation medium showed $95 \%$ of the $\left[{ }^{3} \mathrm{H}\right] 4^{\prime}-\mathrm{N}$-stearoyl2 -deoxycytidine activity in the protein pellet.

When macrophages $\left(\mathrm{P}_{388}\right)$ were loaded with acetylLDL conjugates, the relation between the ligand $\left({ }^{3} \mathrm{H}\right.$ labelled) and cholesteryl ester increment in the cytosol after incubation did not reflect the ratio of these components in the LDL conjugate (tab. 3). The increment of intracellular cholesteryl esters due to acetyl-LDL transport is $1.4 \%$ of total cholesterol load. In contrast, $\left[{ }^{3} \mathrm{H}\right] 4^{\prime}-\mathrm{N}$-stearoyl-2'-deoxycytidine activity is $6.2 \%$ of $\left[{ }^{3} \mathrm{H}\right] 4^{\prime}-\mathrm{N}$-stearoyl-2'-deoxycytidine load. Thus, stoichiometric symport has not occurred. On the other hand, loading with unacetylated $\left[{ }^{3} \mathrm{H}\right] 4^{\prime}-\mathrm{N}$ stearoyl-2'-deoxycytidine LDL leads to almost the same intracellular enrichment of activity when compared with the acetyl-LDL conjugate. However, an increase of intracellular cholesteryl esters was not found, which indicates that no transport of the unacetylated LDL conjugates took place. Furthermore, in transport experiments with free $\left[{ }^{3} \mathrm{H}\right] 4^{\prime}-\mathrm{N}$-stearoyl2 '-deoxycytidine, the presence of bovine serum albu$\mathrm{min}$ in the incubation medium substantially reduced $\left[{ }^{3} \mathrm{H}\right] 4^{\prime}$-N-stearoyl-2'-deoxycytidine uptake in macrophages. Therefore, the presence of an extracellular lipophilic compartment competed for the ligand with transmembrane transport.

Tab. 3. Comparison of internalization of $\left[{ }^{3} \mathrm{H}\right] 4^{\prime}$-N-stearoyl-2' -deoxycytidine as free nucleoside derivative, as LDL conjugate and as acetyl-LDL conjugate in the presence and absence of bovine serum albumin, $40 \mathrm{~g} / 1$, on $\mathrm{P}_{388}$-macrophages. LDLconcentration: $75 \mathrm{mg} / 1$ medium. LDL conjugation: $35 \mu \mathrm{g}\left[{ }^{3} \mathrm{H}\right] 4^{\prime}-\mathrm{N}$-stearoyl-2'-deoxycytidine / mg acetyl-LDL (total cholesterol); $\left.30 \mu \mathrm{g} \mathrm{[}{ }^{3} \mathrm{H}\right] 4^{\prime}-\mathrm{N}$-stearoyl-2'=deoxycytidine / mg LDL (total cholesterol).

The expected coincidence between ligand and LDL-cholesterol internalization was not observed.

Nucleoside
[3H] $4^{\prime}-\mathrm{N}$-stearoyl-2' $\div$ deoxycytidine/acetyl-LDL

$\left[{ }^{3} \mathrm{H}\right] 4^{\prime}-\mathrm{N}$-stearoyl-2'-deoxycytidine/LDL

Free $\left[{ }^{3} \mathrm{H}\right] 4^{\prime}$-N-stearoyl-2'-deoxycytidine

$\left[{ }^{3} \mathrm{H}\right] 4^{\prime}-\mathrm{N}$-stearoyl=2'-deoxycytidine/acetyl-LDL + bovine serum̄ albụmin, $40 \mathrm{~g} / 1$

$\left[{ }^{3} \mathrm{H}\right] 4^{\prime}$-N-stearoyl-2'-deoxycytidine/LDL + bovine serum albumin, $40 \mathrm{~g} / \mathrm{l}$

Free $\left[{ }^{3} \mathrm{H}\right] 4^{\prime}-\mathrm{N}$-stearoyl-2'-deoxycytidine + bovine serum albumin, $40 \mathrm{~g} / 1$
Increase of intracellular cholesterylester

\begin{tabular}{ll}
\hline$\mu \mathrm{g} / \mathrm{mg}$ & Fraction of \\
cell & initial LDL \\
protein & cholesterol
\end{tabular}

(\%)

$\left[{ }^{3} \mathrm{H}\right] 4^{\prime}-\mathrm{N}$-stearoyl-2'deoxycytidine internalization \begin{tabular}{ll}
\hline $\mathrm{ng} / \mathrm{mg}$ & Fraction of \\
cell & initial \\
protein & activity
\end{tabular}

$\begin{array}{ccrc}8.7 & 1.4 & 580 & 6.2 \\ \pm 0 & \pm 0 & 499 & 5.7 \\ \pm 0 & \pm 0 & 1198 & 9.4 \\ 9.3 & 1.6 & 171 & 1.8 \\ \pm 0 & \pm 0 & 143 & 1.7 \\ \pm 0 & \pm 0 & 183 & 1.4\end{array}$


Because the results of the conventional stability tests did not agree with the results of the cell experiments, a new method for testing stability, referred to as the "coincubation test", was developed (30).

The principle of this test is precipitation of LDL with heparin at a certain $\mathrm{pH}$ after coincubation with acetylLDL, which does not precipitate at this $\mathrm{pH}$. This precipitation is independent of drug conjugation. During coincubation of labelled LDL conjugates and acetyl-LDL (potential conjugate acceptor) a switch of the ligand can be detected. Because ligand donor (LDL conjugates) and ligand acceptor (acetyl-LDL) are equimolar with respect to LDL-cholesterol, the maximum redistribution of initial ligand radioactivity is $50 \%$. The redistribution of $\left.{ }^{3} \mathrm{H}\right] 4^{\prime}-\mathrm{N}$-stearoyl-2'deoxycytidine/LDL is accomplished within three minutes, indicating instant instability (fig. 5). On the other hand, of the four tested LDL conjugates, 5'-O-erucoyl-azidothymidine/LDL shows a relatively high stability. $\left[{ }^{125}\right.$ I]LDL serves as control and reveals almost complete stability.

The above results show, that conjugation via solution equilibrium is not an appropriate method for obtaining stable LDL conjugates. Hence, the method of covalent ligand coupling was employed using 4-nitrophenyl-thymidine-ester (19). Thymidine coupling to LDL (19) is limited by protein denaturation, which occurs at a 4-nitrophenyl-thymidine-ester concentration of $10 \mathrm{~g} / \mathrm{l}$ (fig. 6). The maximal loading of thy-

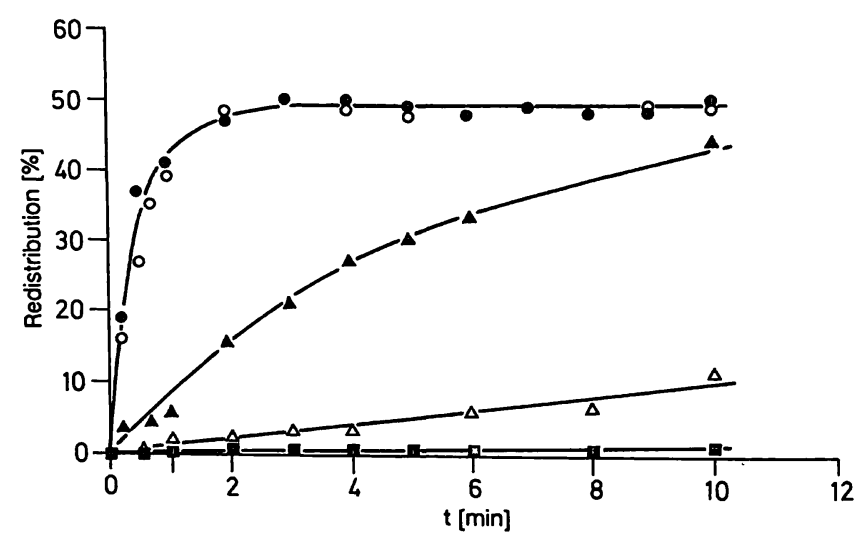

Fig. 5. Coincubation test to assess stability of LDL conjugates: LDL conjugates were coincubated with an equimolar amount of acetylated (unconjugated) LDL-cholesterol for a period of time as indicated. Afterwards the unacetylated LDL was selectively precipitated with heparin. Ligand distribution between supernatant and pellet was determined; a $50 \%$ value is equal to total lability. Note that DMSO addition during preparation of the LDL conjugate $\left(4^{\prime}-\mathrm{N}\right.$-stearoyl-2'-deoxycytidine/LDL) has no significant effect on stability.

- 4'-N-stearoyl-2'-deoxycytidine

O $4^{\prime}$-N-stearoyl-2'-deoxycytidine, $10 \%$ DMSO

$\Delta$ 5'-O-stearoyl-3'-azido-2' $3^{\prime}$-deoxythymidine

$\triangle 5^{\prime}$-O-erucoyl-3'-azido-2'.3'-deoxythymidine

a [ $\left.{ }^{125} \mathrm{I}\right] \mathrm{LDL}$

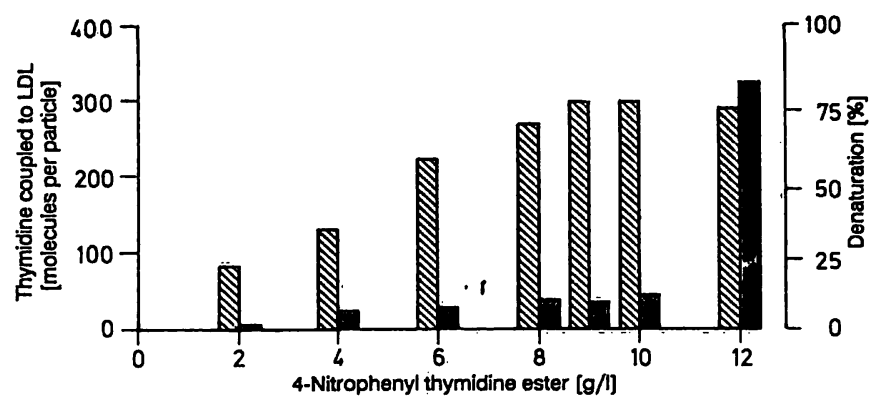

Fig. 6. Efficacy of the covalent coupling reaction: number of thymidine molecules per LDL particle (membrane differential filtration LDL-apheresis) as a function of 4nitrophenyl thymidine ester concentration in the reaction medium. Reaction conditions: $250 \mathrm{mmol} / \mathrm{l}$ borate buffer, $\mathrm{pH} 10.0$, LDL protein concentration $10 \mathrm{mg} / \mathrm{l}$, $4^{\circ} \mathrm{C}$. Admixture of 4-nitrophenyl-thymidine-ester every $5 \mathrm{~min}$. Maximal thymidylation rate equal to 300 thymidine molecules per LDL particle is reached at $10 \mathrm{mg}$ 4-nitrophenyl-thymidine-ester (hatched columns). Further increase of 4-nitrophenyl-thymidine-ester leads to denaturation (black columns) of LDL.

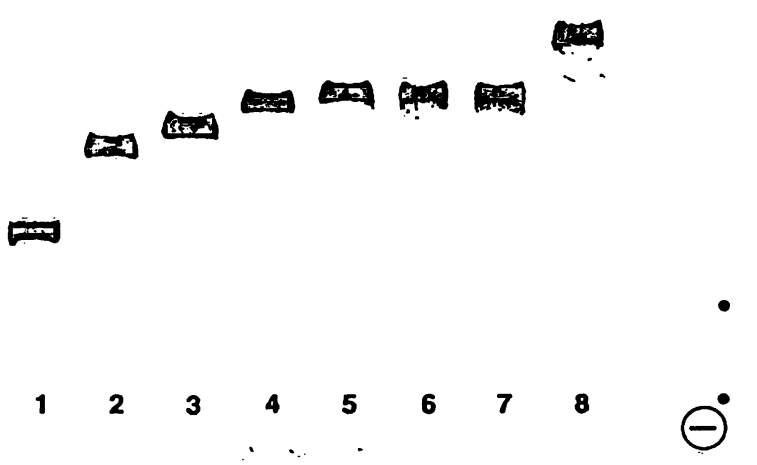

Fig. 7. Agarose electrophoresis (Beckman Parägon ${ }^{1}$ LiPoGel) of thymidine-LDL particles with varying thymidine content.

Lane 1: Native plasma LDL;

lane 2-7: increasing number of thymidine per LDL: lane $2=80$, lane $3=160$, lane $4=240$, lane $5=280$, lane $6=290$ and lane $7=300$;

lane 8: acetyl-LDL.

midine is 300 thymidine molecules per molecule apolipoprotein B. Hence, $88 \%$ of the 338 lysyl residues (38) were coupled. The reaction results in the formation of an amide bond. This implies that the coupled lysyl residues lose their basic property. Consequently, the surface charge of LDL-apolipoprotein B correlates with the thymidylation rate, which is demonstrated by agarose lipoprotein electrophoresis (fig. 7).

Stability of the thymidine-LDL complex has already been demonstrated by agarose electrophoresis. Fur- ther evidence of stability is provided by trichloroacetic acid precipitation: $97-99 \%$ of the initial activity 
$\left(\left[{ }^{3} \mathrm{H}\right]\right.$ thymidine) was found in the pellet. The same amount was found for trichloroacetic acid precipitation of $\left[{ }^{125} \mathrm{I}\right] \mathrm{LDL}$.

The aim of experiments with hepatocytes (HepG2) (fig. 8) was to measure the affinity of thymidine-LDL for the apolipoprotein B receptor. The characteristic inhibition of [ $\left.{ }^{125} \mathrm{I}\right] \mathrm{LDL}$ (substrate) degradation by increasing amounts of unlabelled plasma LDL (inhibitor) in the medium is shown. Replacing the inhibitory LDL by acetylated LDL does not diminish degradation of $\left[{ }^{125} \mathrm{I}\right] \mathrm{LDL}$. If thymidine-LDL is used as a competitive inhibitor, a similar effect, i.e. no competitive inhibition, is seen. Moreover, a small, but detectable increase of $\left[{ }^{125}\right.$ I]LDL degradation occurs, when modified (acetylated or thymidylated) LDL is used as a competitive inhibitor. This effect was reproduced with several modified LDL preparations.

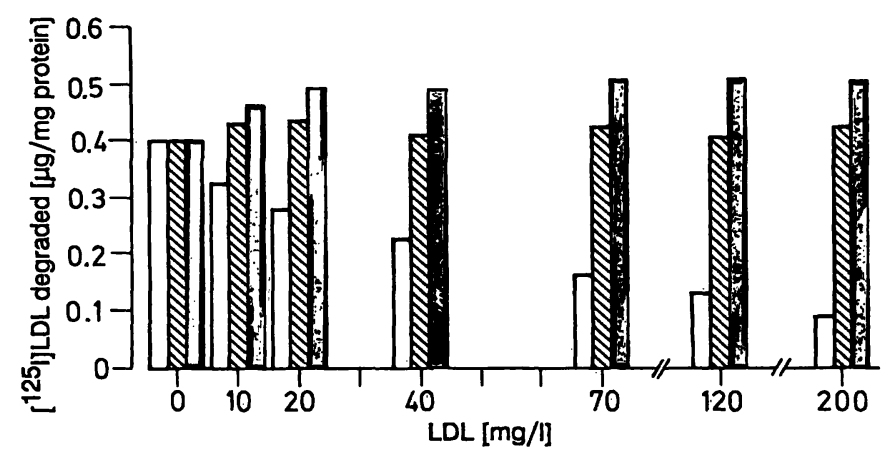

Fig. 8. Cell transport experiments on Hep G2 hepatocytes; competition experiments. Degradation of [ $\left.{ }^{125} \mathrm{I}\right] \mathrm{LDL}(\mu \mathrm{g} /$ $\mathrm{mg}$ cell protein, substrate concentration $10 \mathrm{mg} / 1 \mathrm{me}-$ dium) was determined at increasing concentrations of various, unlabelled LDL preparations. Native LDL (white columns) acts as competitive inhibitor; modified LDL (hatched columins: acetyl; black: thymidine) does not decrease substrate degradation. Incubation conditions: $5 \% \mathrm{CO}_{2}, 37^{\circ} \mathrm{C}, 4 \mathrm{~h}$.

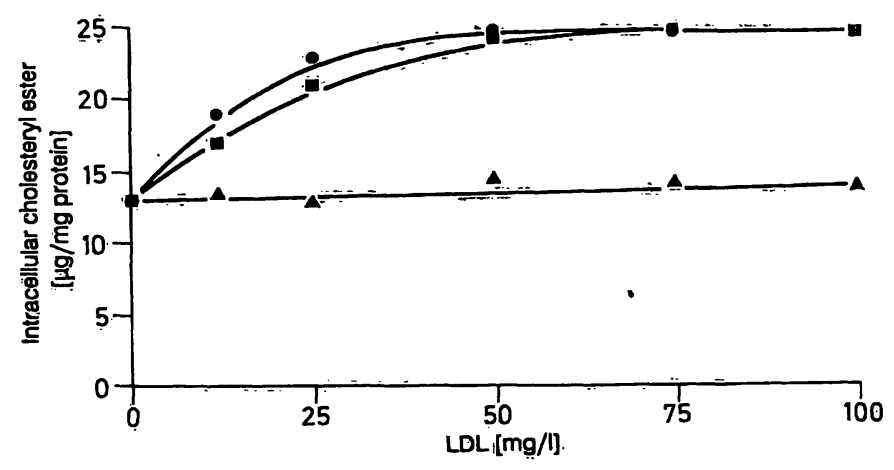

Fig. 9. Cell transport experiments on $\mathrm{P}_{388}$ macrophages. Intracellular cholesterylester content as an indicator of LDL internalization as a function of the LDL concentration in the medium. Native LDL $(\boldsymbol{\Delta})$ does not increase the intracellular cholesterylester content; acetyl-LDL (a) and thymidine-LDL (ब) increase the intracellular cholesterylester content. Incubation conditions: $5 \% \mathrm{CO}_{2}$, $37^{\circ} \mathrm{C}, 4 \mathrm{~h}$.
Thus, thymidine-LDL is not recognized by the apolipoprotein B receptor pathway, otherwise thymidineLDL would inhibit the degradation of $\left[{ }^{125} \mathrm{I}\right] \mathrm{LDL}$ and of plasma LDL.

Figure 9 shows the results of transport experiments with unlabelled LDL particles and macrophages $\left(\mathrm{P}_{388}\right)$. Plasma-derived LDL particles were not taken up by the macrophages, as indicated by the constancy of the intracellular cholesteryl ester content. On the other hand, acetyl-LDL and thymidine-LDL were internalised to the same extent, as shown by the increase of intracellular cholesteryl ester.

\section{Discussion}

A variety of conjugation methods for different LDL compartments has been published, employing several compounds and drugs $(8,9,31,36-39)$. However, nucleosides have not previously been considered as ligands. The aim of this study was to prepare nucleoside-LDL-conjugates, which can be transported selectively into HIV infected cells via LDL receptor pathways.

The results show that amphiphilic nucleoside derivatives conjugated with LDL are not suited for cellselective transport via either of the two LDL receptor pathways, despite the fact that these conjugates show adequate stability in conventional stability tests.

An explanation of this unexpected finding is provided by the results of a new type of experiment, which is referred to as the "coincubation test". In this test instability of the LDL conjugates was demonstrated in the presence of another lipophilic solution compartment (acetyl-LDL). Thus, unspecific uptake is likely to avoid receptor pathways and a direct transfer of the ligand to the cell membrane may occur. Conventional stability tests in pure aqueous media do not a priori reveal these phenomena, despite the fact that unstable conjugates, such as trityl-azidothymidine/ LDL show their character. One may remember, that in equilibrium dialysis direct contact between both lipoprotein solutions is prevented by the dialysis membrane. Thus, only stability in aqueous solutions and not in a heterogeneous system can be demonstrated by the conventional methods.

The results help to interpret some, as yet not fully understood, findings reported in the literature concerning LDL conjugates:

- Iwanik (31) demonstrated, that a substantial amount of daunomycine (16\%) was found in the plasma membrane in $\mathrm{P}_{388}$ cells, when offered as 
LDL conjugate, whereas free daunomycine is found to $2 \%$ in the plasma membrane. This fact may be explained by direct ligand shift from LDL to the plasma membrane.

- Rudling's (9) experiments indicated a small specific uptake of aclacinomycine $A$ in tumour cells (U$251 \mathrm{MG}$ ), when offered as LDL conjugates. Hence, a large fraction of the observed total transport must have been unspecific.

- Vitols (8) demonstrated a major unspecific uptake of anthracycline into white blood cells. In these experiments LDL conjugates were prepared by Krieger's reconstitution method. Hence, the assumed stability was probably only partially maintained.

- Schöneshöfer (32) demonstrated, that probucol in plasma is bound to LDL; its half-life is more than 60 days, hence direct transfer to LDL particles with a half-life of 2 days should have occurred.

Within this frame of reference, the following additional important fact should be considered. Ever since the classical work of Goldstein \& Brown (27), it is common practice to demonstrate specificity of LQL internalization via the apolipoprotein $B$ receptor pathway by adding unlabelled LDL as a competitive inhibitor. When this technique is applied to transport experiments with LDL conjugates, an extensive reduction of ligand uptake is observed. The conclusion however, that this phenomenon is due to displacement of the LDL conjugate from the receptor, may be wrong. If, for instance, the addition of albumin causes a similar reduction, the mechanism must be unspecific. Redistribution of the LDL ligand to now available lipophilic compartments (LDL-excess, bovine serum albumin) takes place, as demonstrated by working up the incubation media with ultracentrifugation. In conclusion, competition experiments with LDL as the competitor are acceptable only when the LDL conjugate is shown to be stable in the coincubation test.

Since the acyl-nucleoside/LDL conjugates exhibited instability, covalent coupling of nucleosides to the protein moiety of the LDL particle was developed. Thymidine was used as a representative compound for dideoxynucleosides. The same coupling reaction can be applied to any type of nucleoside.

The increased covalent binding of thymidine leads to the loss of surface cationicity, and thereby to the loss of apolipoprotein B receptor affinity. Scavenger re- ceptor affinity is implemented instead. This became evident in cell transport experiments, in which competitive inhibition was used as an indicator of receptor-mediated internalization: the uptake of native ${ }^{125} \mathrm{I}$ labelled LDL into HepG2 cells could not be abolished by thymidine-LDL. On the other hand, in macrophages $\left(\mathrm{P}_{388}\right)$, thymidine-LDL was transported in the same way as acetyl-LDL, as indicated by the same degree of enrichment of intracellular cholesteryl esters.

With respect to the type and degree of revealed surface modification, agarose electrophoresis and the results of cell transport experiments are in close agreement. One may remember, that many other modifications (derivatization with methyl-, glucosyl-, malondialdehyde- and hexandione-ligands $(33,18))$, which mask lysyl side chains, lead to the same transport behaviour.

The reported experiments indicate that therapeutic nucleosides can be selectively targeted to macrophages. The enrichment of $10 \mu \mathrm{g}$ cholesteryl ester per mg cell protein ( $\mathrm{P}_{388}$-macrophages) is equivalent to the establishment of $600 \mu \mathrm{mol} / 1$ nucleoside in the cytosol. Total inhibition of reverse transcriptase ${ }^{2}$ ) in human macrophages occurs at $10 \mu \mathrm{mol} / \mathrm{l}$ azidothymidine (34).

However, a prerequisite for pharmacological action of dideoxynucleoside-LDL-complexes is the release of the drug through lysosomal degradation. This remains to be demonstrated by in vitro reverse transcriptase inhibition in infected macrophages.

It is known that macrophages have only a low potential for phosphorylating nucleosides, which is a condition for the therapeutic action of nucleoside analogues (35). But it is the ratio of azidothymidinetriphosphate to thymidine-triphosphate and not the absolute concentrations of these two compounds that is responsible for the reverse transcriptase inhibition effect (34). Thus, the low thymidine kinase activity does not necessarily contradict the proposal to treat macrophages with dideoxynucleosides.

Further experiments are needed to demonstrate whether, in cell cultures of HIV-infected human macrophages, these nucleoside LDL complexes can specifically inhibit HIV replication. A more general consideration of this therapeutic proposal would then be reasonable.

$\left.{ }^{2}\right)$ Enzyme: Reverse transcriptase, RNA-directed DNA polymeräse (EC 2.7.7.49). 


\section{References}

1. Ehrlich, P., Himmelweite, F., M. Marquardt \& Sir Henry Doles (1956) The Collected Papers of Paul Ehrlich. Pergamon Press, Oxford, pp. 596-618.

2. Vitols, S., Gahrton, G., Ost, A. \& Peterson, C. (1984) Elevated Low Density Lipoprotein Receptor Activity in Leucemic Cells with Monocytic Differentiation. Blood 63, $1186-1193$.

3. Vermeer, B. J., Marian, M. D., Wijsman, C., MommaasKienhuis, A. M. \& Ponec, M. (1986) Binding and Internalization of Low Density Lipoproteins in SCC25 Cells and SV40 Transformed Keratinocytes - A Morphologic Study. J. Invest. Dermatol. 86, 195-200.

4. Vitols, S., Gahrton, G., Björkholm, M. \& Peterson, C. (1985) Hypocholesterolaemia in Malignancy Due to Elevated Low Density Lipoprotein Receptor Activity in Tumor Cells: Evidence from Studies in Patients with Leucaemia. Lancet $I I, 1150-1153$.

5. Simpson, E. R., Bilheimer, D. W., MacDonald, P. C. \& Porter, J. C. (1979) Uptake and Degradation of Plasma Lipoproteins by Human Choriocarcinoma Cells in Culture. Endocrinology 104, 8-16.

6. Rudling, M. J., Stahle, L., Peterson, C. \& Skoof, L. (1986) Content of Low Density Lipoprotein Receptors in Breast Cancer Tissue Related to Survival of Patients. Brit. Med. J. $292,580-582$.

7. Gal, D., Ohashi, M., MacDonald, P. C., Buchsbaum, H. J. \& Simpson, E. R. (1981) Low Density Lipoprotein as a Potential Vehicle for Chemotherapeutic Agents and Radionuclides in the Management of Gynecologic Neoplasms. Am. J. Obstet. Gynecol. 139, 877-885.

8. Vitols, S., Gahrton, G. \& Peterson, C. (1984) Significance of the Low Density Lipoprotein Receptor Pathway for the in Vitro Accumulation of Ad-32 Incorporated into LDL in Normal and Leukemic White Blood Cells. Cancer Treatment Reports 68, 515-520.

9. Rudling, M. J., Collins, V. P. \& Peterson, C. (1983) Delivery of Aclacinomycin A to Human Glioma Cells in Vitro by the Low Density Lipoprotein Pathway. Cancer Res. 43, 4699-4605.

10. Masquelier, M., Vitols, S. \& Peterson, C. (1986) Low Density Lipoprotein as a Carrier of Antitumoral Drugs: in Vivo Fate of Drug-Human Low Density Lipoprotein Complexes in Mice. Cancer Res. 46, 3842-3847.

11. Roy, S. \& Wainberg, M. A. (1989) Role of the Mononuclear Phagocyte System in the Development of Acquired Immunodeficiency Syndrome (AIDS). J. Leukocyte Biology $43,91-97$.

12. Gartner, S., Markovits, P., Markovits, D. M., Kaplan, M. H., Gallo, R. C. \& Popovic, M. (1986) The Role of Mononuclear Phagocytes in HTLV-III/LAV Infection. Science 233, 215-219.

13. Crowe, S., Mills, J. \& MacGrath, M. S. (1987) Quantitative Immunocytofluorographic Analysis of CD4 Surface Antigen Expression and HIV Infection of Human Periphal Blood Monocyte/Macrophàges. AIDS Res. Hum. Retrov. 3, 135-145.

14. Lazo, P. A. \& Tsischlis, P. N. (1990) Biology and Pathogenesis of Retroviruses. Semin. Oncol. 17, 269-294.

15. Wells, K. H., Byrne, B. C. \& Poiesz, B. J. (1990) Detection, Prevention, and Treatment of Retroviral Infections. Semin. Oncol. 17, 295-320.

16. Broder, S., Mitsuya, H., Yarchoan, R. \& Pavlakis, G. N. (1990) Antiretroviral Therapy in AIDS. Ann. Int. Med. $113,604-618$.

17. Mazzone, T., LOpez, C. \& Bergstreasser, L. (1987) Modification of Very Low Density Lipoproteins Leads to Macrophage Scavenger Receptor Uptake and Cholesteryl Ester Deposition. Arteriosclerosis 7, 191-197.
18. Fogelman, A. M., Shechter, I., Seager, J., Hokom, M., Child, J. S. \& Edwards, P. A. (1979) Malondialdehyde Alteration of Low Density Lipoproteins Leads to Cholesteryl Ester Accumulation in Human Monocyte-Macrophages. Proc. Natl. Acad. Sci. USA 77, 2214-2218.

19. Schultis, H. W. (1990) Lipoproteine, ihre chemische Modifizierung und ihr Einsatz als Arzneistoffträger. Dissertation. Freie Universität Berlin.

20. v. Baeyer, H., Kochinke, F., Marx, M., Schwertfeger, R., Schulten, D., Kaczmarczyk, G. \& M. Kessel (1983) Flow Controlled Selective Plasma-Ultrafiltration with Online Membraneregeneration by Backflush Technique. Trans. Amer. Soc. Artif. Intern. Org. 29, 739-743.

21. Radding, C. M. \& Steinberg, D. (1960) Studies on the Synthesis and Secretion of Serum Lipoproteins by Rat Liver Slices. J. Clin. Invest. 36, 1560-1569.

22. Cardin, A. D., Witt, K. R., Barnhart, C. L. \& Jackson, R. L. (1982) Sulfhydry] Chemistry and Solubility Properties of Human Plasma Apolipoprotein B. Biochemistry 21, $4503-4511$.

23. Schultis, H.-W., Baeyer, H. v., Neitzel, H. \& Riedel, E. (1990) Functional Characteristics of LDL Particles Derived from Various LDL-Apheresis Techniques Regarding LDLDrug-Complex Preparation. J. Lipid. Res. 31, $2277-2284$.

24. Lowry, O. H., Rosebrough, N. J., Farr, A. L. \& Randall, R. J. (1951) Protein measurement with the Folin phenol reagent. J. Biol. Chem. 193, 265-275.

25. Karlin, J. B., Juhn, D. J., Fless, G., Scanu, A. M. \& Rubenstein, A. H. (1978) Measurement of Rhesus Monkey (Macaca Mulatta) Apolipoprotein B in Serum by Radioimmunoassay: Comparison of Immunoreactivities of Rhesus and Human Low Density Lipoproteins. J. Lipid. Res. 19, 197-206.

26. Basu, S. K., Goldstein, J. L., Anderson, R. G. W. \& Brown, M. S. (1976) Degradation of Cationized Low Density Lipoprotein and Regulation of Cholesterol Metabolism in Homozygous Familial Hypercholesterolemia Fibroblasts. Cell Biology 73, 3178-3182.

27. Goldstein, J. L. \& Brown, M. S. (1974) Binding and Degradation of Low Density Lipoproteins by Cultured Human Fibroblasts. J. Biol. Chem. 249, 5153-5162.

28. Schmitz, G., Niemann, R., Brennhausen, B., Krause, R. \& Assmann, G. (1985) Regulation of High Density Lipoprotein Receptors in Cultured Macrophages: Role of AcylCoA: Cholesterol Acyltransferase. EMBO Journal 4, 2773-2779.

29. Havekes, L., v. Hinsbergh, V., Kempen, H. J. \& Emeis, J. (1983) The Metabolism in Vitro of Human Low Density Lipoprotein by the Human Hepatoma Cell Line Hep G2. Biochem. J. 214, $951-958$.

30. Schultis, H. W., v. Baeyer, H., Neitzel, H. \& Riedel, E. (1990) Analysis of the stability of lipoprotein-drug complexes with a new incubation test. Fresenius J. Anal. Chem. $337,125-126$.

31. Iwanik, M. J., Shaw, K. V., Ledwith, B. J., Xanovich, S. \& Shaw, J. M. (1984) Preparation and Interaction of a Low Density Lipoprotein-Daunomycin Complex with P388 Leukemic Cells. Cancer Res. 44, 1206-1215.

32. Schöneshöfer, M., Heilmann, P., Schmidt, L. \& Schwartzkopf, W. (1989) Automated Column Liquid Chromatographic Determination of Probucol in Human Serum and Lipoproteinfractions. J. Chromatography 490, 230-235.

33. Steinbrecher, U. P., Witztum, J. L., Kesaniemi, Y. A. \& Elam, R. L. (1984) Comparison of Glucosylated Low Density Lipoprotein with Methylated or Cyclohexandionetreated Low Density Lipoprotein in the Measurement of Receptor Independent Low Density Lipoprotein Catabolism. J. Clin. Invest. 71, 960-964. 
34. Perno, C. F., Yarchoan, R., Cooney, D. A., Hartman, N. R., Gartner, S., Popovic, M., Hao, Z., Gerrard, T. L., Wilson, Y. A., Johns, D. G. \& Broder, S. (1988) Inhibition of Human Immunodeficiency Virus (HIV/HTLV-III) Replication in Fresh and Cultured Human Peripheral Blood Monocytes/Macrophages by AZT and Related 2',3'-Dideoxynucleosides. J. Exper. Med. 168, 1111-1125.

35. Richman, D. D., Kornbluth, R. S. \& Carson, D. A. (1987) Failure of Dideoxynucleosides to Inhibit Human Immunodeficiency Virus Replication in Cultured Human Macrophages. J. Exper. Med. 166, 1144-1149.

36. Krieger, M., Brown, M. S., Faust, J. R. \& Goldstein, J. L. (1978) Replacement of Endogenous Cholesteryl Esters of Low Density Lipoprotein with Exogenous Cholesteryl Linoleate. J. Biol. Chem. 253, 4093-4101.
37. Lundberg, B. (1987) Preparation of Drug-Low Density Lipoprotein Complexes for Delivery of Antitumoral Drugs via the Low Density Lipoprotein Pathway. Cancer Res. 47, 4105-4108.

38. Samadi-Baboli, M., Favre, G., Blancy, E. \& Soula, G. (1989) Preparation of Low Density Lipoprotein-9-Methoxy-Ellipticin Complex and its Cytotoxic Effect Against L1210 and P388 Leukemic Cells in Vitro. Eur. J. Clin. Oncol. 25., 233-241.

39. Halbert, G. W., Stuart, J. F. B. \& Florence, A. T. (1985) A Low Density Lipoprotein-Methotrexate Covalent Complex and its Activity Against L1210 Cells in Vitro. Cancer Chemother. Pharmacol. 15, 223-227.

Prof. Dr. Ebërhard Riedel Institut für Biochemie der Freien Universität Berlin

Limonenstraße 7

W-1000 Berlin 45

Bundesrepublik Deutschland 